\title{
HUBUNGAN GAYA KEPEMIMPINAN KEPALA SEKOLAH DENGAN KINERJA GURU DI SD NEGERI SE-KECAMATAN SIMPANG EMPAT
}

\author{
Tri Widya Ningsih ${ }^{1}$, Erlinda Simanungkalit ${ }^{2}$, Masta Marselina Sembiring ${ }^{3}$, \\ Dila Handayani ${ }^{4}$ \\ Surel: erlindapgsdunimed@gmail.com
}

\begin{abstract}
This study aims to determine the relationship between the principal's leadership style and teacher performance in public elementary schools in Simpang Empat District. The research method is correlation. The sample of this research is using purposive sampling technique, so the sample of this research is the teachers of SD Negeri Se-District Simpang Empat who have civil servant status, totaling 33 people. The results showed that the leadership style of the principal of the SD Negeri in Simpang Empat was categorized as moderate with an average score of 74.42. Meanwhile, the performance of elementary school teachers in Simpang Empat sub-district is in the sufficient category with an average score of 102.45. Furthermore, there is a relationship between the principal leadership style variable $(X)$ and the teacher performance variable $(Y)$ with rcount > rtable with a value comparison of $(0.437>0.344)$. This shows that there is a positive relationship between the principal's leadership style and the performance of public elementary school teachers in the Simpang Empat District which has a moderate level of correlation. Then the t-test obtained tcount of 2,689 while ttable obtained from the critical list in the table against $=0.05$ of 2,039 means tcount $>$ ttable with a comparison value of $(2,689$ > 2.039) so Ha is accepted and $\mathrm{HO}$ is rejected.
\end{abstract}

Keywords: Principal Leadership Style, Teacher Performance.

\begin{abstract}
ABSTRAK
Penelitian ini bertujuan untuk mengetahui hubungan gaya kepemimpinan kepala sekolah dengan kinerja guru di SD Negeri se-Kecamatan Simpang Empat. Metode Penelitian yaitu korelasi. Sampel penelitian ini yaitu menggunakan teknik purposive sampling, maka sampel penelitian ini adalah guru-guru SD Negeri Se-Kecamatan Simpang Empat yang sudah berstatus PNS yang berjumlah 33 orang. Hasil penelitian menunjukkan bahwa gaya kepemimpinan kepala sekolah SD Negeri Se-Kecamatan Simpang Empat tergolong berkategori sedang dengan nilai rata-rata sebesar 74,42. Sedangkan kinerja guru SD Negeri Se-Kecamatan Simpang Empat tergolong dalam kategori cukup dengan nilai rata-rata sebesar 102,45. Selanjutnya terdapat hubungan antara variabel gaya kepemimpinan kepala sekolah (X) dengan variabel kinerja guru (Y) dengan $r_{\text {hitung }}>r_{\text {tabel }}$ dengan perbandingan nilai sebesar $(0,437>0,344)$. Hal ini menunjukkan terdapat hubungan yang positif antara gaya kepemimpinan kepala sekolah dengan kinerja guru SD Negeri di Se-Kecamatan Simpang Empat yang mempunyai tingkat korelasi sedang. Kemudian uji $t$ diperoleh $t_{\text {hitung }}$ sebesar 2,689 sedangkan $t_{\text {tabel }}$ yang diperoleh dari daftar kritis pada tabel terhadap $\alpha=0,05$ sebesar 2,039 artinya $t_{\text {hitung }}>t_{\text {tabel }}$ dengan perbandingan nilai sebesar $(2,689>2,039)$ sehingga $\mathrm{H}_{\mathrm{a}}$ diterima dan $\mathrm{H}_{0}$ ditolak.
\end{abstract}

Kata Kunci : Gaya Kepemimpinan Kepala Sekolah, Kinerja Guru. PENDAHULUAN

1,2,3 Universitas Negeri Medan

${ }^{4}$ Universitas Tjut Nyak Dhien 
Pendidikan merupakan pengerahan tenaga guru dengan tugas penuh untuk mengendalikan siswa menuju pekembangannya. Rendahnya kualitas sumber daya manusia merupakan kendala yang mendasar bagi pembangunan dan perkembangan ekonomi nasional. Sifat sumber daya manusia sebenarnya harus ditingkatkan secara progresif dan terus-menerus melalui kerangka sekolah yang berkualitas baik dalam pengajaran formal dan non-formal, mulai dari pelatihan penting hingga pendidikan lanjutan. Upaya untuk menghasilkan pendidikan yang berkualitas, banyak faktor yang terlibat salah satu diantaranya yaitu sekolah. Sekolah adalah lembaga pendidikan yang dipercaya masyarakat untuk menyediakan sumber daya manusia yang dibutuhkan dalam perkembangan bangsa. Keberhasilan pendidikan di sekolah terutama ditentukan oleh kemampuan kepala sekolah dalam mengelola tenaga kependidikan sekolah..

Setiap kepala sekolah dihadapkan pada tantangan untuk melaksanakan pengembangan pendidikan secara terarah, berencana dan berkesinambungan. Kepala sekolah sebagai pimpinan harus mampu memajukan sekolah yang dipimpinnya dengan beberapa kemampuan, seperti administrasi, memiliki komitmen tinggi dan luwes dalam melaksanakan tugasnya. Gaya kepemimpinan kepala sekolah yang baik dapat mengupayakan peningkatan kinerja guru melalui program pembinaan kemampuan tenaga kependidikan.

Dalam hal ini kinerja guru sangat diperlukan dalam proses pembelajaran dikelas agar tujuan pembelajaran dapat terlaksana dengan baik. Fokus penelitian yang dilakukan peneliti ialah kinerja guru dalam proses pembelajaran meliputi: pelaksanaan kegiatan perencanaan pembelajaran, pelaksanaan kegiatan pembelajaran, evaluasi/penilaian pembelajaran dan tindak lanjut evaluasi. Hasil observasi pada 15 November 2020 yang peneliti lakukan mengenai kinerja guru dalam pembelajaran sudah cukup baik dimana dalam hal ini guru sudah mempersiapkan rencana pelaksanaan pembelajaran (RPP) namun dalam pelaksanaan kegiatan pembelajaran guru kurang memanfaatkan ketersediaan sarana dan prasarana yang dimiliki sekolah untuk menunjang kegiatan pembelajaran. Peneliti melihat bahwa guru-guru sebagian besar masih menggunakan metode ceramah pada proses pembelajaran tanpa adanya variasi metode pembelajaran lainnya.

Berdasarkan hasil wawancara pada 16 November dengan salah satu guru yaitu Ibu Aznita Br Panjaitan, beliau mengatakan bahwa kepala sekolah kurang menerapkan gaya kepemimpinan secara optimal untuk memimpin bawahannya. Hal ini didasari dari banyak kebijakan yang dilakukan oleh sekolah bukan sepenuhnya berasal dari pemikiran kepala sekolah selaku pemimpin, melainkan kebijakan tersebut didasari 
Tri Widya Ningsih, Erlinda Simanungkalit, Masta Marselina Sembiring : Hubungan ...

oleh pemikiran guru selaku bawahannya. Kemudian banyak dari tugas yang diberikan kepala sekolah kepada guru tidak dipertimbangkan berdasarkan kemampuan yang dimiliki oleh guru tersebut. Sedangkan dari hasil observasi peneliti masih menemukan ada beberapa kepala sekolah yang terlambat datang kesekolah tidak sesuai jam masuk sekolah.

Gaya kepemimpinan adalah kualitas seorang individu untuk mempengaruhi orang lain atau asosiasi, dengan tujuan bahwa orang lain mau dan siap untuk bergerak dan meniru perspektif dan karakter mereka sendiri untuk mencapai tujuan. Wahyudi (2012:123) menyatakan bahwa gaya kepemimpinan adalah standar perilaku yang dilakukan oleh seorang individu di sekitar kemudian berdampak pada orang lain, lebih tepatnya gaya inisiatif yang diterapkan individu kepada bawahan sehingga tujuan yang ideal dapat tercapai. Mulyasa (2017: 195) gaya kepemimpinan adalah contoh pimpinan yang biasa ketika mempengaruhi bawahan, apa yang dipilih untuk mempengaruhi banyak orang membentuk gaya pemerintahannya Berdasarkan pendapat para ahli, maka dapat disimpulkan bahwa gaya kepemimpinan adalah sikap dan perilaku seorang pemimpin terhadap bawahan dalam mencapai tujuan bersama, setiap pemimpin mempunyai gaya kepemimpinan yang diterapkan agar tujuan yang telah ditetapkan dapat tercapai dengan baik.
Gaya kepemimpinan yang otokratis, pemimpin bertindak sebagai diktator terhadap anggota-anggota kelompoknya. Kekuatan seorang bawahan diktator hanya dibatasi oleh hukum. Artinya sebagai seorang pimpinan hanyalah penampilan dan pemberian perintah. Komitmen bawahan atau individu mereka hanya untuk mengikuti dan melakukan, mereka tidak boleh berdebat atau membuat ide. Dalam hal ini kepala sekolah bebas membuat peraturan sendiri dan peraturan tersebut harus ditaati dan diikuti oleh guru-guru, staf dan pegawai lainnya. Jelas tergambarkan bahwa kepala sekolah dengan gaya kepemimpinan otokratis ialah Kepala sekolah yang kurang siap mendengarkan atau peduli terhadap ide, usul, dan pendapat kreatif guru, staf, dan pegawai lainnya. Dalam gaya kepemimpinan laissez faire ini, bawahan tidak terlalu memberikan otoritas. Jenis ini dicirikan sebagai memungkinkan individu untuk melakukan apa yang mereka butuhkan. Perintis yang memiliki tempat dengan jenis ini tidak memberikan kontrol dan perbaikan untuk dibuat oleh individu mereka. Pembagian tugas dan kerjasama diserahkan kepada sekelompok individu, tanpa pedoman atau ide dari inisiatif. Untuk situasi ini kepala pimpinan dan tidak memberikan model dalam inisiatifnya. Gaya kepemimpinan ini kepala sekolah bersifat pasif serta memberikan kesempatan total kepada guru dan staf. Semua pilihan dalam menyelesaikan tugas dan pekerjaan diserahkan 
sepenuhnya kepada guru dan staf sekolah. Gaya kepemimpinan demokratis mengartikan otoritasnya bukan sebagai pimpinan, melainkan sebagai inovator di tengah-tengah orang-orang yang dipimpin. Perintis berbasis suara secara konsisten berusaha untuk memperkuat individu mereka untuk bekerja secara bermanfaat untuk mencapai tujuan bersama. Dalam kegiatan dan usahanya, pimpinan umumnya berdasarkan pada kepentingan dan kebutuhan bawahannya, dan memikirkan kapasitas dan kapasitas bawahannya.

Kepala sekolah secara konsisten melibatkan pendidik, staf dan perwakilan lainnya dalam memutuskan, kepala seperti itu secara konsisten memperhatikan penilaian atau manifestasi dari pengajar, staf, dan pekerja lain di bawahnya untuk mengembangkan sekolahnya. Sebagai pemimpin, prinsipnya lebih mementingkan kepentingan bersama daripada kepentingan diri sendiri dalam rangka membina hubungan dan kerjasama yang baik dan harmonis, saling membantu dalam melaksanakan tanggung jawab sehari-hari, dan membina lingkungan yang sehat bagi guru, staf, dan karyawan lainnya. Kepala sekolah bekerja untuk mempromosikan perencanaan pendidikan di sekolah dengan senang dan senang. Kinerja guru adalah hasil melaksanakan tugas-tugas dalam proses pembelajaran yang dibebankan kepada guru, dilihat melalui kegiatan perencanaan pembelajaran, pelaksanaan pembelajaran, evaluasi atau penilaian pembelajaran dan tindak lanjut hasil penilaian. Banyak faktor yang mempengaruhi kinerja guru, diantaranya menurut Mahmudi (2005) sebagai berikut:

a. Sebuah individu, meliputi: informasi, kemampuan, kapasitas, keyakinan diri, inspirasi dan tanggung jawab setiap orang.

b. Faktor gaya kepemimpinan, antara lain: kualitas dalam memberikan penghiburan, energi, kursus dan dukungan yang diberikan oleh kepala.

c. Faktor kelompok, meliputi: kualitas dalam menawarkan bantuan dan keinginan yang diberikan oleh mitra dalam keadaan kelompok, kepercayaan pada rekan kerja, kekompakan dan kedekatan kelompok.

d. Faktor kerangka kerja, meliputi: kerangka kerja, kantor kerja atau yayasan yang diberikan oleh asosiasi, siklus hierarkis dan budaya pelaksanaan di dalam asosiasi.

e. Komponen yang berorientasi pada konteks, meliputi: faktor penekan dan perubahan iklim luar dan dalam.

Menurut Wibowo (2014:87) mengatakan bahwa kinerja guru dipengaruhi oleh: pengetahuan, kemampuan, sikap, gaya kerja, kepribadian,minat, dasar-dasar nilai, kepercayaan dan gaya kepemimpinan. Berdasarkan faktor-faktor yang mempengaruhi kinerja guru yang telah dikemukakan oleh para ahli, terlihat bahwa gaya kepemimpinan 
Tri Widya Ningsih, Erlinda Simanungkalit, Masta Marselina Sembiring : Hubungan ...

merupakan salah satu faktor dalam kinerja guru. Sehingga dapat dikatakan bahwa kinerja guru yang baik melibatkan gaya kepemimpinan kepala sekolah yang memimpin sekolah tersebut.

\section{METODE PENELITIAN}

Jenis penelitian ini adalah penelitian kuantitatif. Menurut Sugiyono (2017:15) penelitian kuantitatif merupakan penelitian yang berlandaskan pada filsafat positivisme, digunakan untuk meneliti pada populasi atau sampel tertentu. Metode yang digunakan adalah korelasi. Menurut Arikunto (2013: 4) penelitian korelasi adalah penelitian yang dilakukan oleh peneliti untuk mengetahui tingkat hubungan antara dua variabel atau lebih, tanpa melakukan perubahan, tambahan atau manipulasi terhadap data yang memang sudah ada. Sesuai dengan sifatnya korelasional, penelitian ini memusatkan perhatian pada tingkat keeratan hubungan gaya kepemimpinan kepala sekolah dengan kinerja guru. Dalam penelitian ini menggunakan dua variabel bebas dan terikat. Adapun yang menjadi variabel bebas dalam penelitian ini adalah gaya kepemimpinan kepala sekolah sedangkan variabel terikat dalam penelitian ini adalah kinerja guru.

Tempat penelitian yang dilaksanakan di $4 \quad$ SD Negeri Kecamatan Simpang Empat yaitu: SD Negeri 011917, SD Negeri 010027, SD Negeri 010035 dan SD Negeri 010028. Penelitian ini dilaksanakan pada bulan Maret sampai Mei pada
Semester II Tahun Ajaran 2020/2021 di SD Negeri Kecamatan Simpang Empat. Populasi dalam penelitian ini yaitu seluruh guru-guru SD Negeri seKecamatan Simpang Empat yang berjumlah 216 guru sedangkan sampel dalam penelitian ini menggunakan teknik purposive sampling (pertimbangan tertentu). Sampel dalam penelitian ini yaitu 33 guru yang mengajar di SD Negeri se-Kecamatan Simpang Empat.

Teknik pengumpulan data yang dilakukan yaitu: (a) Metode dokumentasi (b) Kuesioner/angket yang digunakan ialah angket tertutup. (c) Observasi. Teknik analisis deskriptif digunakan untuk menganalisis data. yaitu menggunakan data kuantitatif, sehingga instrumen yang digunakan menghasilkan data numerik atau angka. Tabulasi data untuk masing-masing variabel dilakukan terhadap skor yang diperoleh dengan menggunakan bantuan Microscoft Excel sehingga akan diperoleh tabel distribusi frekuensi dan histogram untuk setiap variabel penelitian. Sedangkan uji persyaratan analisis data menggunakan uji normalitas, uji homogenitas dan uji linearitas. Selanjutnya uji hipotesis menggunakan uji korelasi product moment dan uji hipotesis untuk melihat signifikansi antar 2 variabel yang diteliti.

\section{HASIL PENELITIAN DAN PEMBAHASAN}

Berdasarkan hasil yang di peroleh mengenai hubungan gaya 
kepemimpinan kepala sekolah dengan kinerja guru SD Negeri se-Kecamatan Simpang Empat dilakukan melalui teknik pengumpulan data berupa angket (kuesioner) yang diisi oleh guru-guru SD Negeri se-Kecamatan Simpang Empat yang sudah berstatus Pegawai Negeri Sipil (PNS) sebanyak 33 responden. Penelitian ini menggunakan uji validitas konstruk dimana uji instrumen penelitian dilakukan dengan cara mengkonsultasikan angket kepada para ahli (judgment expert) dalam bidang pendidikan, yaitu Dosen Jurusan Pendidikan Pra Sekolah dan Sekolah Dasar FIP UNIMED.

Informasi yang dikumpulkan dari hasil penyebaran kuesioner kepada responden dapat dilihat di bawah ini. bahwa terdapat hubungan positif gaya kepemimpinan kepala sekolah dengan kinerja guru SD Negeri se-Kecamatan Simpang Empat. Dilihat dari hasil uji kecenderungan gaya kepemimpinan kepala sekolah SD Negeri seKecamatan Simpang Empat diperoleh skor berkategori tinggi sebesar 9,09\%, berkategori sedang $54,55 \%$, berkategori cukup 21,21\% dan berkategori rendah $15,15 \%$. Data yang didapat dari hasil angket gaya kepemimpinan kepala sekolah diperoleh rata-rata sebesar 74,42. Aspek yang diteliti dalam penelitian ini yaitu gaya kepemimpinan otokratis, gaya kepemimpinan laissez faire dan gaya kepemimpinan demokratis.

\section{Frekuensi}

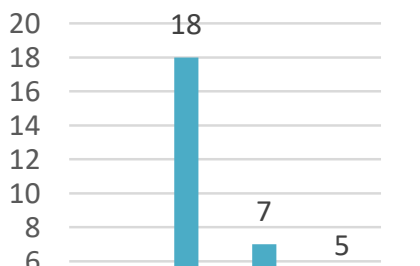

\section{Gambar 1. Hasil Penyebaran Kuesionar}

Selanjutnya dilihat dari hasil kecenderungan kinerja guru SD Negeri se-Kecamatan Simpang Empat diperoleh skor berkategori tinggi sebesar $21,21 \%$, berkategori sedang sebesar 18,19\%, berkategori cukup sebesar $51,51 \%$ dan berkategori rendah sebesar 9,09\%. Data yang didapat dari hasil angket kinerja guru diperoleh rata-rata sebesar 102,45. Aspek yang diteliti dalam penelitian ini yaitu perencanaan program kegiatan pembelajaran, pelaksanaan kegiatan pembelajaran, evaluasi/penilaian pembelajaran dan tindak lanjut evaluasi.

\section{Frekuensi}

17

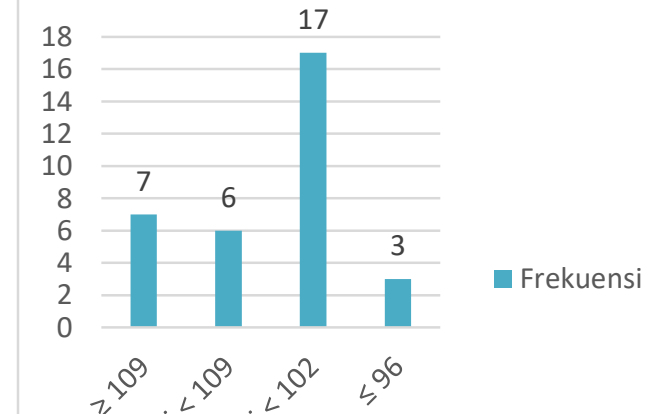


Tri Widya Ningsih, Erlinda Simanungkalit, Masta Marselina Sembiring : Hubungan ...

\section{Gambar 1. Hasil Penyebaran Kuesionar}

Berdasarkan hasil korelasi antara hubungan gaya kepemimpinan kepala sekolah $(\mathrm{X})$ dengan kinerja guru (Y) dengan koefisien korelasi sebesar 0,437 dengan kategori tingkat hubungan yang sedang, sedangkan dilihat dari daftar $r_{\text {tabel }}$ diperoleh $r_{\text {tabel }}$ sebesar 0,344 pada $\alpha=0,05$ maka jika dibandingkan kedua nilai tersebut $\mathrm{r}_{\mathrm{xy}}$ $>r_{\text {tabel }}$ yaitu $(0,437>0,344)$. Melihat dari hasil analisa data dapat disimpulkan bahwa kedua variabel memiliki hubungan yang positif. Hasil pengujian hipotesis dengan menggunakan uji $\mathrm{t}$ diperoleh $\mathrm{t}_{\text {hitung }}$ sebesar 2,698 sedangkan tabel pada taraf signifikan 5\% diperoleh $\mathrm{t}_{\text {tabel }} \mathrm{dk}=$ n-2 $(33-2=31)$ yaitu sebesar 2,039 sehingga dapat dikatakan bahwa thitung $>t_{\text {tabel }}$ yaitu $(2,698>2,039)$. Maka dapat disimpulkan hipotesis yang berbunyi "Terdapat hubungan yang signifikan antara gaya kepemimpinan kepala sekolah (X) dengan kinerja guru (Y) SD Negeri se-Kecamatan Simpang Empat".

\section{SIMPULAN}

Dari hasil penelitian yang telah dilakukan maka kesimpulan yang dapat diperoleh, adalah:
- Gaya kepemimpinan kepala sekolah SD Negeri se-Kecamatan Simpang Empat dalam kategori sedang dengan nilai rata-rata sebesar 74,42. Sedangkan kinerja guru SD Negeri se-Kecamatan Simpang Empat dalam kategori cukup dengan nilai rata-rata sebesar 102,45 .

- Terdapat hubungan antara variabel gaya kepemimpinan kepala sekolah (X) dengan variabel kinerja guru (Y) dengan $r_{\text {hitung }}>r_{\text {tabel }}$ sebesar $(0,437>0,344)$. Hal ini menunjukkan terdapat hubungan positif antara gaya kepemimpinan kepala sekolah dengan kinerja guru di SD Negeri se-Kecamatan Simpang Empat yang mempunyai tingkat korelasi sedang.

- Terhadap uji $t$ diperoleh $t_{\text {hitung }}>t_{\text {tabel }}$ sebesar (2,698>2,039). Sehingga hipotesis berbunyi: "Terdapat hubungan yang signifikan antara gaya kepemimpinan kepala sekolah dengan kinerja guru di SD Negeri se-Kecamatan Simpang Empat"

\section{DAFTAR RUJUKAN}

Beni, Ahmad dan Ii, Sumantri. 2014. Kepemimpinan. Bandung: Pustaka Setia.

Idawati. 2013. Gaya Kepemimpinan Kepala Sekolah Dan Kinerja Guru. Jurnal Ekletika, 1 (2), h.153-162.

Mulyasa, E. 2007. Menjadi Kepala Sekolah Profesional. Bandung: Remaja Rosdakarya.

Priansa, D. J. 2019. Kinerja dan Profesionalisme Guru. Bandung: Alfabeta. 
Purwanto, M. N. 2008. Administrasi dan Supervisi Pendidikan. Bandung: Remaja Rosdakarya.

Rachmawati, Tuti. 2013. Penilaian

Kinerja Profesi Guru dan Angka Kreditnya. Yogyakarta: Gava Media.

Sari, Anggita Permata. 2014.

Hubungan Antara Gaya

Kepemimpinan Kepala Sekolah Dengan Kinerja Guru Di SDN. No 187/1 Teratai. Jambi: FKIP Universitas Jambi.

Simanjuntak, Payaman J. 2005. Manajemen dan Evaluasi Kinerja. Jakara: Lembaga Penerbit Fakultas Ekonomi Universitas Indonesia.

Sitepu, Desi Natalia. 2019. Hubungan Gaya Kepemimpinan Kepala Sekolah Terhadap Kinerja Guru Di SD Negeri Kecamatan STM Hulu Tahun 2018/2019. Medan: Universitas Quality.

Sondang. 1971. Filsafat Administrasi. Jakarta: Gunung Agung.

Sudjana, Nana dan Ibrahim. 2014.

Penelitian dan Penilaian Pendidikan. Bandung: Sinar Baru Algensido.

Sugiyono. 2017. Metode Penelitian Pendidikan Pendekatan Kuantitatif, Kualitatif dan $R \& D$. Bandung : Alfabeta.

Suradinata, Ermaya. 1997. Pemimpin dan Kepemimpinan. Jakarta: Gramedia Pustaka Umum.

Timpe,A.Dale. 1992. Kinerja. Jakarta: Gramedia Asri Media.

Wahyudi. 2012. Kepemimpinan

Kepala Sekolah Dalam
Organisasi Pembelajar.

Bandung : Alfabeta.

Wibowo. 2014. Manajemen Kinerja.

Jakarta : Rajawali 